LAPORAN KASUS

\title{
EFEKTIFITAS TOXIN BOTULLINUM UNTUK MANAJEMEN BLEFAROSPASME ESSENSIAL DAN SPASME HEMIFASIAL
}

\author{
Hendriati \\ Sub Bagian Rekonstruksi dan Okuloplastik-Bagian Ilmu Kesehatan Mata \\ Fakultas Kedokteran Universitas Andalas/RS. Dr. M. Djamil PADANG \\ E-mail : irin970@yahoo.com
}

\begin{abstract}
Abstrak
Untuk mengukur efektifikas toxin Botullinum pada kasus-kasus okuloplastik (blefarospasme essensial dan spasme hemifasial.

Laporan kasus 16 pasien yang terdiri dari 14 kasus spasme hemifasial dan 2 kasus blefarospasme essensial. Digunakan 6 vial toxin Botullinum. Vial pertama digunakan untuk pasien spasme hemifasial dan 1 pasien blefasrospasme di minggu berikutnya. vial kedua dan ketiga masing-masing digunakan untuk 2 pasien spasme hemifasial. Vial keempat digunakan untuk pasien blefarospasme yang menggunakan vial pertama (setelah 6 bulan), dan 1 pasien spasme hemifasial yang menggunakan vial kedua ( setelah 4 bulan) dan 1 pasien spasme hemifasial baru. Setelah 1 minggu, toxin Botullinum vial keempat digunakan untuk 6 pasien spasme hemifasial dan 1 pasien blefarospasme essensial yang menggunakan vial pertama 8 hari berikutnya (setelah 7 bulan).

Terdapat 16 pasien pada studi ini ; 14 spasme hemifasial dan 2 blefarospasme essensial. Pada 5 pasien dilakukan injeksi ulangan dengan jangka waktu yang berbeda. Tidak ditemukan efek samping pada pasien-pasien ini.

Toxin Botulinum efektif untuk manajemen spasme hemifasial dan blefarospasme essensial tetapi efeknya temporer. Pada studi ini, jangka waktu injeksi ulangan bervariasi sekitar $4-7$ bulan pada 5 pasien.
\end{abstract}

Kata Kunci : Toxin Botulinum toxin, spasme hemifasial, blefarospasme

\begin{abstract}
To asses Botulinum Toxin efficacy in oculoplastic cases (blepharospasm and hemifacial spasm).

A case report on 16 patients consisted of 14 hemifacial spasms and 2 essential blepharospasm. Six vials of botulinum toxin were used. First vial was used for two patients of hemifacial spasm and one blepharospasm patient one week later. Second and third vials were used each for two patients of hemifacial spasms. Fourth vial was used for one blepharospasm patient from first vial user (after six month), one hemifacial spasm from second vial user (after four months) and one new hemifacial spasm. After one week, Botulinum toxin from fourth vial was used for one new patient of hemifacial spasm. Fifth and sixth vial was used for six
\end{abstract}


hemifacial spasms and eight days later for one blepharospasm from first vial user (after seven months).

There were 16 patients in this serial study; 14 hemifacial spasms and 2 blepharospasms. Five patients had reinjections with different duration. There is no side effect in those patients.

Botulinum toxin is effective in treatment of hemifacial spasm and blepharospasm, but the effects are temporary. In this study, reinjections durations about four to seven months in five patients.

Key word : Botulinum toxin, hemifacial spasm, blepharospasm 


\section{PENDAHULUAN}

Botullinum Toxin (Bo Tox) merupakan suatu neurotoksin yang dihasilkan oleh Clostridium Botullinum, yang berbahaya bagi manusia. Clostridium Botullinum pertama kali di identifikasi tahun 1897 di Belgia oleh Prof. Emile van Ermengem yang menginvestigasi kasus keracunan makanan setelah mengkonsumsi ham terkontaminasi (peristiwa di Elleselle Music Society). Bakteri ini dinamakan berdasarkan penyakit yang disebabkannya, botulisme, suatu bentuk keracunan makanan yang mematikan dikaitkan dengan sosis daging (botulus $=$ sosis, dalam bahasa latin). ${ }^{(1-4)}$

Terdapat 7 serotipe toksin botulinum (A, B, C, D, E, F dan G). Serotipe A, B dan E menyebabkan penyakit yang disebabkan makanan (food-borne) dengan paralisisflaksid motorik dan sarafotonom. Tipe B pertama kali ditemukan pada 1910 danisolasitipe A dimulai tahun 1920an. Bo Tox bekerja dengan menginhibisi pengeluaran asetilkolin pada proses kontraksi otot secara voluntir. Kontraksi otot secara voluntir terjadi setelah adanya rangsangan aksi potensial yang melewati suatu saraf menuju otot. Jika aksi potensial ini mencapai sinap pada neuromuscular junction, akan merangsang influx kalsium menuju sitoplasma dari ujung saraf yang akan meningkatkan konsentrasi kalsium hingga asetilkolin berfusi dengan membran menggunakan suatu kompleks protein. Kompleks protein terdiri atas tiga tipe protein : VAMP (synatobrevin), SNAP-25 (synaptosomal associated protein) dan syntaxin. Bo Tox-A bekerja dengan memblok SNAP-25 dan Bo Tox-B memblok VAMP. ${ }^{(7,8)}$

D.Allan Scott, seorang dokter mata dari Smith-Kettlewell Eye Research Foundation meneliti zat yang menyebabkan paralise otot transien dengan menggunakan toksin botullinum tipe A, serta melakukan tes klinis pertama pada manusia tahun 1978. Penelitiannya menggunakan botullinum untuk terapi strabismus dipublikasikan tahun 1980. Hal ini kemudian mengarahkan penggunaan toksin botullinum tipe A oleh dokter mata dalam terapi blefarospasme dan spasme hemifasial. Nama Bo Tox pun menjadi nama umum yang dikenal luas. Bo Tox-A telah disetujui oleh Food and Drug Administration di Amerika Serikat pada tahun 1989 untuk penanganan strabismus, blefarospasme dan spasme hemifasial. $^{(1,2,5,6)}$

\section{Blefarospasme}

Blefarospasme adalah suatu penutupan kelopak mata secara involunter yang disebabkan oleh kontrak siototorbikularisokuli. Benign Essential Blepharospasme adalah suatu distoniafokal bilateral, yang ditandai dengan spasmeumum yang bermula sebagai kebutaan ringan (mild twitches) atau pun mengedip yang sering dan sesuai perjalanan waktu dapat menjadi kontraksi hebat. Periode episode involunterini dapat membatasi kemampuan pasien untuk berkendara, membaca, atau melakukan aktivitas harian. Lama kelamaan kondisi ini berlanjut hingga pasien secara fungsional menjadi buta akibat ketidak mampuan episodik membuka kelopak mata. ${ }^{(6,12-14)}$

Penyebab pasti blefarospasme belum diketahui, etiologi diperkirakan bersifat multifaktorial, terdiri dari gangguan-gangguan ekstrapiramidal dan batang otak ataupun faktor-faktor psikologis. Blefarospasme dapat ditangani oleh pendekatan medis ataupun pembedahan. ${ }^{(6,12-14)}$ 


\section{Epidemiologi}

Laporan tentang prevalensi blefarospasme berkisar dari 12 per satu juta penduduk di Jepang hingga 133 per satu juta penduduk pada suatu penelitian di Italia. Kebanyakan penelitian epidemiologis menunjukkan bahwa blefarospasme esensial merupakan suatu gangguan autosomal dominan. Blefarospasme esensial terjadi paling sering pada wanita di atas usia 50 tahun. $^{(13)}$

\section{EtiologidanPatofisiologi}

Penyebab pasti blefarospasme belum diketahui. Diperkirakan etiologi blefarospasme bersifat multi faktor, terdiri dari gangguan-ganggua nekstra pyramidal dan batang otak ataupun faktor-faktor psikologis. Penelitianpenelitian pencitraan (imaging) menunjukkan dan yalesifokal pada batang otak bagian rostral, diencephalon, dan ganglia basalis. Pada kasus blefarospasme esensial, terdapat bukti bahwa ada distoniafokal yang disebabkan disfungsi ganglia basalis atau batang otak. Penelitian pada pasien-pasien dengan blefarospasme esensial menggunakan MRI menunjukkan adanya suatu hiper aktifitas sirkuit kortikal ${ }^{(6,13,14)}$

\section{GambaranKlinis}

Tanda-tanda awal termasuk mengedip yang berlebihan saat terekspos dengan angin, cahaya matahari, ataustres, dengan progresivitas sesuai berjalannya waktu hingga dapat terjadi spasme involunter $\mathrm{M}$. orbikularisokuli secara bilateral. Dalam beberapa kasus, spasme dapat terjadi secara hebat dan menetap. Pasienpasien sering mengeluhkan jatuhnya kelopak mata (droopy eyelids), fotofobia, kaburnya penglihatan, serta ketidak mampuan membuka mata. Apraksia pembukaan kelopak mata dapat terjadi bersamaan dengan blefaro spasme dan penting untuk identifikasi keberadaannya karena tidak respon dengan baik terhadap pengobatan injeksi botulinum toxin. $(6,13,15)$

\section{Penggunaan BoTox pada Blefarospasme}

Injeksi berulang secara periodik dari botulinum toxin type A (BoTox) merupakan terapi pilihan untuk blefarospasme. Injeksi zat ini pada dosis terapi menghasilkan denervasi kimiawi dan paralisis otot terlokalisir. Injeksi botulinum toxin biasanya efektif namun temporer. Onset of action rata-rata adalah 2-3 hari, dan efek puncak rata-rata terjadi pada sekitar 7-10 hari setelah injeksi. Masa efeknya juga bervariasi namun biasanya 3-4 bulan, di mana terjadinya pengulangan spasme dan injeksi ulang dapat dipertimbangkan. ${ }^{(8,10,16)}$

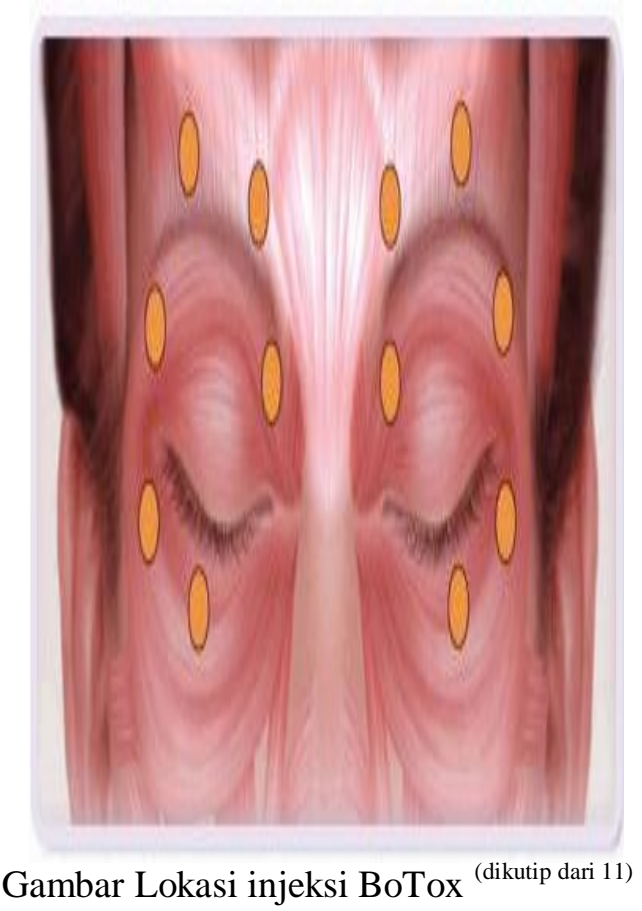




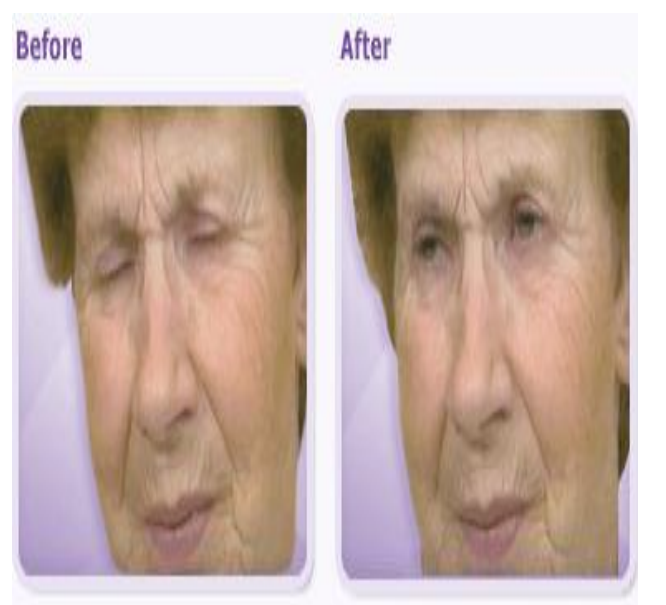

Gambar sebelum dan sesudah injeksi BoTox (dikutip dari 11)

\section{Spasme Hemifasial}

Spasmehemifasialis ditandai dengan kontrak turumumintermiten dari keseluruhan wajah dan jarang bilateral. Spasmeini sering muncul saa ttidur. Spasme biasanya dimulai dari otot orbikularisokuli, kemudian menyebar ke otot-otot wajah lainnya. Kondisi ini harus dibedakan dengan blefarospasme. Spasme hemifasialis sering terkait dengan kelemahan Nervus Fasialisipsilateral. Dalam kebanyakan kasus, penyebab kasus spasme hemifasialis adalah kompresinervus Fasialis pada batang otak. MRI sering menunjukkan adanya pembuluh yang ekstasi. Injeksi periodik botulinum toksin merupakan salah satu pilihan, selain dari bedah dekompresi Nervus fasialis.(17-19)

\section{Epidemiologi}

Spasme hemifasial ini biasa muncul pada usia antara 40 hingga 79 tahun. Cenderung lebih banyak pada wanita, dimana prevalensi pada wanita 14,5 dalam 100000 wanita, sedang pada pria 7,4 dalam 100000 pria dalam suatu penelitian epidemiologis di Minnesota. Diperkirakan prevalensi lebih banyak pada orang Asia dibanding Kaukasia, meski belum dibuktikan dalam penelitian epidemiologis. ${ }^{(20)}$

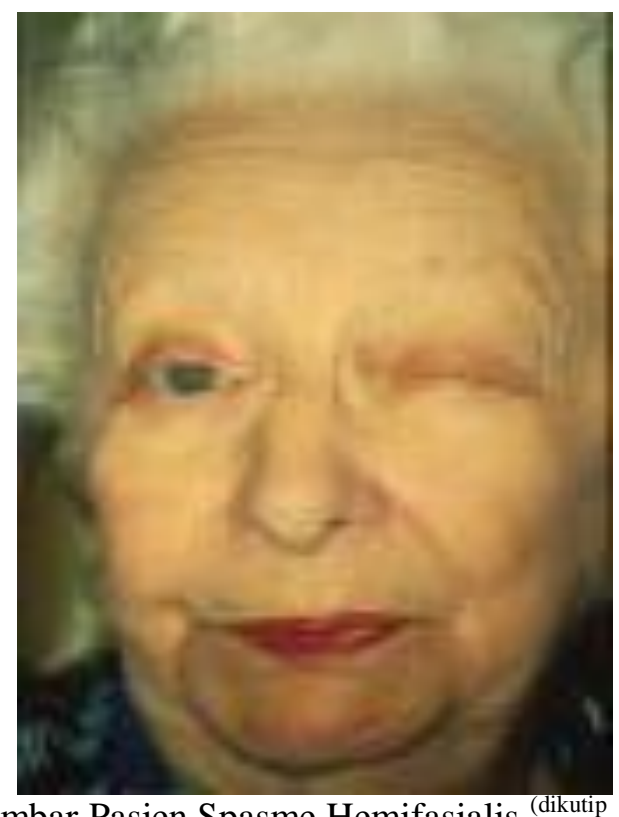

Gambar Pasien Spasme Hemifasialis dari 21)

\section{Penggunaan Botox-A pada Spasme Hemifasial}

BoTox merupakan terapi firstline untuk pasien-pasien spasme hemifasialis. Penggunaannya telah dilaporkan mengarah pada perbaikan kualitas hidup pasien. Elston pertama kali melaporkan tentang pemakaian BoTox pada 6 pasien spasme hemifasialis tahun $1986 .^{(18,19)}$

Suatu tinjauan terhadap penggunaan BoTox pada spasme hemifasialis menunjukkan bahwa telah terdapat banyak penelitian open-label dan beberapa penelitian double-blind placebo-controlled, kesemuanya mengikutsertakan lebih dari 2000 pasien. Tingkat keberhasilan berkisar antara $75 \%$ hingga $100 \% .^{(11,18,20)}$

Efek samping yang pernah dilaporkan seperti dry eyes, ptosis, dan kelemahan kelopak mata serta wajah. Namun hanya bersifat sementara dan belum ada efek samping sistemik serius yang dilaporkan. ${ }^{(19-22)}$ 


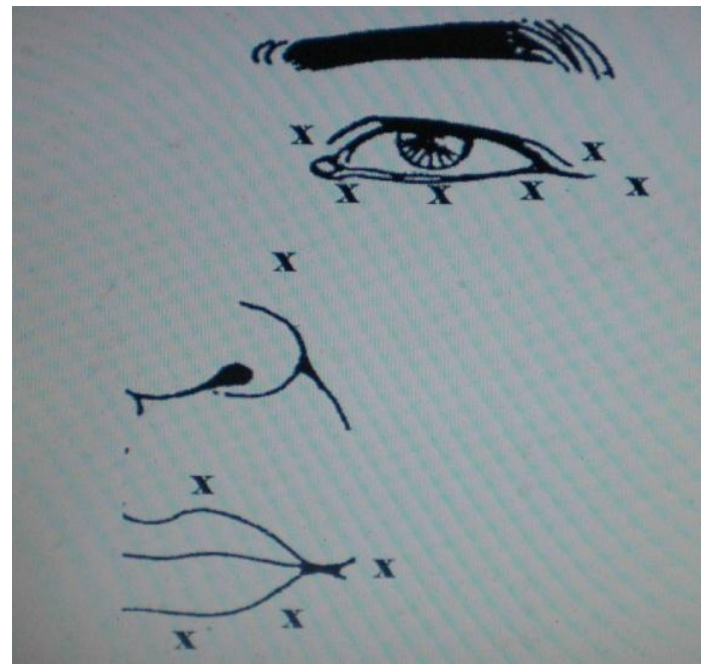

Lokasi injeksi BoTox pada pasien spasme Hemifasialis (dikutip dari 22)

\section{LAPORAN KASUS}

Telah dilakukan injeksi toksin botullinum terhadap 16 orang pasien, 2 orang dengan diagnosa Blefarospasme dan 14 orang lagi dengan Hemifasialspasme. Ada 5 orang pasien yang telah melakukan suntikan ulangan.

Tabel 1. Distribusipasien yang dilakukan injeksi toksin botullinum

\begin{tabular}{cccc}
\hline & & \multicolumn{2}{c}{ Jeniskelamin } \\
\cline { 3 - 4 } Diagnosis & jumlah & male & Female \\
\hline Blefarospasm ODS & 2 & - & 2 \\
HemifacialSinistra & 8 & 2 & 6 \\
HemifacialDextra & 6 & 1 & 5 \\
\hline & 16 & 3 & 13 \\
\hline
\end{tabular}

Tabel 2. Waktu injeksi pertama dan injeksi ulangan toksin botullinum

\begin{tabular}{llll}
\hline Pasien & $\begin{array}{l}\text { Tanggal injeksi } \\
\text { pertama }\end{array}$ & $\begin{array}{l}\text { Pengulangan } \\
\text { yang pertama }\end{array}$ & $\begin{array}{l}\text { Pengulangan } \\
\text { yang kedua }\end{array}$ \\
\hline 1 & $04-07-2009$ & 6 bulan & 6 bulan \\
2 & $11-07-2009$ & 7 bulan & \\
3 & $19-08-2009$ & 4,5 bulan & 4 bulan \\
4 & $01-01-2010$ & 4,5 bulan & \\
5 & $06-01-2010$ & 6,5 bulan & 6 bulan \\
\hline
\end{tabular}

Pada sebagian besar pasien hari injeksi dilakukan bersamaan dengan haridilusi, sebagian kecil lagi penyuntikan dilakukan menggunakan toksin yang telah dilakukan dilusi sebelumnya dan di simpan di dalam lemari pendingin paling lama 2 minggu. 


\section{PEMBAHASAN}

Toksin botullinum telah digunakan lama dalam bidang penyakit mata, yaitu untuk kasus strabismus, blefarospasme dan hemifasialspasme.

Toksin botullinum dalam sediaan berbentuk powder, dilarutkan (dilusi) dengan larutan fisiologis $(\mathrm{Na}$ $\mathrm{Cl}$ 0,9\%) ke dalam botol yang vaccum. Penting untuk menjaga botol yang vaccumini, karena bila tidak vaccum lagi berkemungkinan sediaan sudah berkurang potensinya. Obat sebaiknya diinjeksikan pada hari yang sama dengan dilusi, karena bila di injeksikan pada hari yang berbeda dengan hari dilusi dikhawatirkan potensinya juga akan berkurang.

Injeksi dilakukan sub kutan pada daerah-daerah tertentu. Pada daerah pipi injeksi dilakukan per pendikular karena otot danlemak yang tebal.

Pada kasus-kasus yang dilaporkan ini, penyuntikan pertama dilakukan bersamaan dengan tanggal dilusi. Pada umumnya pasien mulai merasa nyaman setelah 1 minggu penyuntikan sampai 4 bulan, setelah itu pasien mulai merasakan timbulnya kembali keluhan. Setelah 4 bulan biasanya gejala mulai timbul kembali sehingga pasien memerlukan suntikan ulangan.

Efek samping yang ditimbulkan akibat injeksi toksinini dapat terjadi bervariasi mulai dari rasa kebas, merah dan bengkak di tempat injeksi, mata berair, ektropion ringan bahkan ptosis, tetapi itu semua bersifat reversibel. Pada kasus-kasus yang dilaporkan ini efek samping yang ditemui hanya berupa mata berair yang hilang dalam 1 bulan. Semua pasien merasakan nyaman karena kelopak mata dan wajahnya tidak bergerak-gerak lagi.

\section{KESIMPULAN}

Toksin botullinum efektif digunakan untuk terapi blefarospasme dan spasmehemifasial tetapi efeknya temporer. Bisanya pasien memerlukan penyuntikan ulangan dalam $4-7$ bulan berikutnya. Efek samping hampir tidak ada, dan kalau pun ada bersifat reversibel.

\section{KEPUSTAKAAN}

1. Tucker N. Botox: Ironing Out the Wrinkles in Your Technique. In Techniques in Ophthalmology 1(1):2003, 4552.

2. Moriarty, KC. Historical Background. In Botulinum Toxin in Facial Rejuvenation Mosby, Edinburg 2004, 1-2.

3. Gerritsen VB. From sausages to wrinkles. In Protein Spotlight, issue 19, February 2002.

4. Treacy P. The Uses of Botox in Neurology. In Ailesbury Media. June 21, 1-3.

5. Zaidi Z. The Increasing Popularity of Botox Injection. In Pakistan Journal of Dermatology. Vol 57 no 2, February 2007, 53-54.

6. AAO. The Patient with Eyelid or Facial Abnormalities. In BCSC Section 5 2008-2009 Neuroophthalmology, 273-90.

7. Moriarty, KC. Botulinum toxin: Mode of Action and Serotypes. In Botulinum Toxin in Facial Rejuvenation Mosby, Edinburg 2004, 3-8. 
8. Pullman SL. The Myriad Uses of Botulinum Toxin. In Annals of Internal Medicine. Vol 143.no 11. December 2005, 838-839.

9. Horwarth-Winter J, Botulinum Toxin A Treatment of Patient Suffering from Blepharospasm and Dry Eye. In $\mathrm{Br} \quad \mathrm{J}$ Ophthalmology 2003, 87; 5456.

10. FongKS. Botulinum Toxin. In Clinical Ophthalmology, An Asian Perspective; Ang CL, Ed. Saunders Elsevier, 2005 Singapore, 475-478.

11. Allergan Team. The Medical Uses of BOTOX. BOTOX Treatment for Blepharospasm and Strabismus. Accessed from www.botoxmedical.com August 2009.

12. Tow SLC, Cullen JF. Disorders of the Facial Nerve and Blepharo spasm. In Clinical Ophthalmology, An Asian Perspective; Ang CL, Ed. Saunders Elsevier, Singapore 2005, 743-745.

13. Kenney C, Jankovic J. Botulinum Toxin in the Treatment of Blepharospasm and Hemifacial Spasm. In Journal of Neural Transmission (2008), 115, 585-591.

14. AAO. eriocularMalposisitions and Involutional Changes. In BSCS Section 7 2008-2009 Orbit, Eyelids, and Lacrimal System, 201-255.
15. Schicatano J, Basso MA, Evinger C. Animal Model Explain the origin of Cranial Dystonia Benign Essential Blepharospasm. In Journal Neurophysiology 1997, 77, 2842-2846.

16. Salam A, Sing AJ, Innes JR, Melia B. A Novel Temporary Treatment Remedy for Blepharospasm. In Eye (2004) 18, 324-325.

17. Bharman TA, Pranhakar S. Botulinum toxin treatment of hemifacial spasm and blepharospasm: objective response evaluation. In Neurology India 1999, 47; 3; 206-209.

18. Defazio G. Botulinum Toxin. A Treatment for Primary Hemifacial Spasm. In Archieve Neurology. Vol 59. March 2002, $418-420$.

19. Au WL, Tan LCS, Tan AKY. Hemifacial Spasm in Singapore, Clinical Characteristic and Patient's Perceptions. In Annals Academy of Medicine, pg 3248.

20. Tan NC, Chan LL, Tan EK. Hemifacial spasm and Involuntary Facial Movements. In QJ Med 2002; 95: 493-500.

21. Chew YC. Botulinum Toxin: A Poison for Some, A Potion in Oculoplastics. In The Singapore Family Physician Jul-Sept 2002 Vol 28 (3), 2532. 
22. Poonyathalang A. In Letters. Japan Journal
Ophthalmology. Vol 49, 2005, 328. 